\title{
UNITED STATES-CHINA DICHOTOMY AND ITS IMPACT ON POST COVID- 19 GLOBAL POLITICS: A CRITICAL ANALYSIS
}

\author{
Md. Saifullah Akon ${ }^{a}$
}

\begin{abstract}
COVID-19 pandemic, a disaster for humankind in the twenty-first century, has posed a significant impact over the already established US-centred global order. This established order has been challenged by the rise of China, particularly due to some uneven trade war between the two global giants: the United States and China. This US-China dichotomy is further enhanced due to the outbreak of the current COVID-19 pandemic. The inward policy of the United States during the pandemic and the growing cooperation of China in preventing the pandemic is establishing China as a savior to the coronavirusaffected countries. Considering the rivalry between the United States and China amid the pandemic, the main objective of the paper is to find out their global responses to COVID19 and how they maximise their opportunities to lead the post-COVID-19 global order. This article argues that China's 'One Belt, One Road (OBOR)' policy could be one of the forefront issues for Chinese leaders to lead the post-COVID-19 global order due to Trump's inward 'America First' policy. Finally, the article examines the challenges of China to formulate its desire to changing global order having the US-China dichotomy and geopolitical barriers as well.
\end{abstract}

Keywords: COVID-19 pandemic, US-China dichotomy, global order, OBOR

\section{INTRODUCTION}

Towards the end of 2019, the world witnessed, and still is witnessing, a new and an unprecedented experience in the form of COVID-19 pandemic. In particular, this is the first time since World War II that the number of deaths due to the coronavirus has changed the established world system. When the coronavirus was first identified in December 2019 in Wuhan, China (Chatterjee et al., 2020), it may have been unthinkable that the virus could invade the entire world so violently and change the course of world values and politics. Even, many countries had initially miscalculated the threat of it. But over time, as the coronavirus began to manifest its terrible form and spread beyond the border of Asia to the western countries one by one, a different kind of war against the virus began worldwide. It is like an endless battle of the world with an unseen enemy.

Following the first outbreak of the coronavirus (COVID-19) in December 2019, the World Health Organization (WHO) declared it a global pandemic and issued a

\footnotetext{
a Md. Saifullah Akon (msakon27@gmail.com) is a Lecturer in Japanese Studies at the University of Dhaka, Bangladesh.
} 
warning to the world (Coronavirus Declared Global Health Emergency, WHO, 2020). Soon after, the whole world adopted a 'lockdown policy' and states began to close their respective borders. As a result, the flow of the world system and foreign trade became stooped, and above all, the whole world was plunged into an economic catastrophe (Covid-19 and the Inevitable Economic Catastrophe, 2020). This new economic disaster and the global powers' - US' and China's - responses to prevent the spread of the coronavirus further have led the world to a new crisis. This emerging crisis is bringing to the fore some new realities of international politics to the world, having two possibilities: first, whether American dominance will remain impenetrable, and second, the possibility of a new world order led by China.

The United States had established its dominance over the world through the collapse of the Soviet Union in the early 1990s (Layne, 1993). But, President Trump's 'America First' policy (Szuplat, 2017), especially the failure of the United States during the coronavirus pandemic, has exposed the weakness of the Americans. Like the United States, other established global powers also failed to take preventive measures against the pandemic globally. Criticism is also growing about the failure and ineffectiveness of many global and regional organisations. For example, the European Union, as a supranational organisation, has also failed to develop an inclusive and integrated cooperation plan in the political, economic, and health sectors to combat the current pandemic crisis (Fertl, 2020).

On the other hand, under the extraordinary leadership of Xi Jinping, China has been able to create a strong position in international politics (Fravel, 2010). China's flagship 'One Belt, One Road (OBOR)', whose main objective is to increase the speed of international trade by increasing connectivity (Jinchen, 2016), is making China a reliable country, particularly to the South Asian and African developing countries. A large number of countries today depend on China in various sectors. China's increasing trade relations with other countries help to make China the second-largest economy. Besides economic development, China gradually is becoming one of the key actors in international politics. Particularly in the Middle East, where the United States has ruled for the last few decades, China's growing presence in that region (Lons, Fulton, Sun, \& Tamimi, 2019) has put the United States in a difficult position.

Amid the COVID-19 pandemic, while coronavirus-affected countries have failed to seek the cooperation of global powers, only China has come forward to help them. China has provided medical assistance to meet the needs of countries, which has increased China's reputation globally (Letzing, 2020). Such increasing engagement with the coronavirus-affected countries is seen as China's sharing the global responsibility -a basic feature to be the global leader. Now, it is important to justify how China emerges as a trusted responsible power and how they share the global responsibility in the postCOVID-19 pandemic. On the other hand, the inward policies of the Trump administration and the rising debate over the role and capabilities of international and regional organisations in combatting the pandemic are creating a vacuum in global leadership. It remains to be seen to what extent China can fill this gap in international politics with its 
capable leadership. This paper seeks to answer this question by discussing the US-China dichotomy before and during the COVID-19 pandemic.

\section{METHODOLOGY}

The study follows the qualitative method of research approaches. Under the qualitative research approach, data has been collected from both academic and non-academic sources. Academic articles, books and journals were explored, while newspapers, magazines, and websites were used for non-academic resources which help the writer to understand the basic idea of COVID-19 pandemic and its impact on international politics, particularly following the US-China dichotomy. After reviewing the literature related to the current pandemic and global politics, the paper analyses the responses of both the United States and China as individual global actors to combat the COVID-19 pandemic, and the role of liberal institutions as well. Besides, it helps to get the perception of China's OBOR policy and its desire to change the global order amid the COVID-19 pandemic. This paper, after reviewing the necessary documents, critically analyses the challenges and possibilities of China to lead the post-COVID-19 world order under its flagship OBOR projects.

\section{INTERNATIONAL POLITICS DURING COVID-19}

The world system seems to have collapsed with the COVID-19 outbreak. More than half of the world's population is in a lockdown situation. Educational institutions, businesses and world communications have been shut down. The world economy is stagnant. There has never been such a catastrophe in the world since WWII. No one could have even imagined that an invisible virus could stop the whole world in this way. In addition to the daily life of the people, the COVID-19 has also hit international politics.

Today, the international system is shaped mainly by the idea of globalisation (Murtezaj, 2010) and neoliberal policies (Wikan, 2015) where the creation of connectivity, interdependency, and organisation is paramount, and no state can survive without socio-political and economic proximity. Sometimes, states, particularly small states, in terms of economy and military power, are over-dependent on other global powers. The COVID-19 pandemic has dealt a major blow to this established international system. The whole world has started to re-think their global relations by giving up the dependency as well as neoliberal policies. The nature of tight connectivity is more dangerous in the contemporary world, which is correctly pointed out by Parag Khanna in his Connectography (2016) where he stated that the race of connections of the twentyfirst century would replace the $20^{\text {th }}$ century's arms race. The COVID-19 has provided fuel to this debate on whether such connectivity is a threat or a blessing to humankind. Besides this increasing debate of globalisation, states are now thinking more about nontraditional security than traditional security, which soon will reduce the intensity of this arms race and bring issues like health security to the fore. 
Amid the current pandemic, liberal institutions - both regional and international have failed to take the lead in preventing the COVID-19 pandemic in one hand, and their limitations have been exposed to the world, on the other. The United Nations (UN) as the international highest body, and the European Union (EU), South Asian Association for Regional Cooperation (SAARC), and Association for Southeast Asian Nations (ASEAN) as regional organisations have failed to operate successfully. The coronavirus pandemic has shattered Europe's traditional alliances (Pinos \& Radil, 2020) - a big advertisement of Western civilisation for the last half-century. Similarly, the G20, which emerged as an important platform after the 2008 financial crisis, is not playing an effective role today. The G20 summit which was held in a teleconference in the last week of March after the outbreak of the coronavirus, had focused on international cohesion to prevent the impending collapse of the global economy in the fight against the coronavirus (Wintour \& Rankin, 2020), but failed to reach a convincing effective decision.

On the other hand, states are now moving towards 'self-help' theory and have begun to prioritise their national interests. As a result, the attitude of the states towards the 'international community', which exists on the concept of problem solving based on cooperation, is about to change. In particular, in a US-centered world order, where the United States is supposed to play a leading role in the pandemic, the United States has become somewhat isolated by adopting an inward policy. Conversely, the US National Security Strategy, particularly President Trump, declares that the return of great power competition with Russia and China is the greatest threat to US national security (Kroenig, 2020). Such an inward policy of the United States and the failure of the liberal institutions have created a void in international politics. In such a situation, there is a possibility of a big change in the leadership of the post-COVID-19 global order. China's growing ties with countries around the world and its single groundbreaking efforts to prevent the further spread of the pandemic are establishing China as a worthy claimant to global leadership.

\section{UNITED STATES AND CHINA'S RESPONSES AMID COVID-19 AND THE INFERENCE OF THEIR DICHOTOMY}

\section{The United States}

Since the collapse of the Soviet Union, the United States has emerged as a single power and has maintained its dominance for decades. The huge economy and the strongest military have helped the country to rule the world. Also, for decades it has asserted its authority by sending troops to different parts of the world with an aggressive attitude. After 9/11, the United States made a big move through military invasion in the Middle East (Al-Sayyid et al., 2002). Besides, its active participation and its leading role to any crisis across the world had helped the United States to sit in global leadership.

At the beginning of the twenty-first century, China has emerged as a major obstacle to the unipolar global order of the United States (Schweller, 2011). Increasing trade relations with a good number of countries; increased participation in the global crisis; growing proximity to the United States' enemy states i.e. Iran (Mcgregor, 2020); 
and greater acceptance by developing countries have made China unnecessarily confronted by the United States. Besides, in the new polarisation of the world economy, the tough financial system has become stronger than arms. Now, instead of focusing on war, everyone is focusing on strengthening their economy, which appears to be a major blow to the US arms trade.

On the other hand, since the onset of the coronavirus pandemic, questions have been raised worldwide about the role of the United States. In the past, the United States had been at the forefront of any global emergency, and under its great leadership, countries had been able to overcome those disasters. However, since the beginning of the COVID-19 pandemic, the failure of the United States (Fuchs, 2020) has been exposed to the world. Not only is the US administration in a state of disarray in controlling the pandemic, its rogue and inhumane mentality are also being exposed. The United States is nowhere near dealing with the global crisis. President Trump, who came to power with a campaign of extremist nationalism and anti-globalisation (Chandy \& Seidel, 2016), has long been on the verge of secession.

The fragile healthcare system, economic downturn, and the growing military expenditures are starting somewhat of a crisis within the United States, pushing them to adopt inward policies. According to a report published by CNBC on 20 November 2019, the United States had spent about US\$6.4 trillion on the war in the Middle East and Asia since 2001 (Macias, 2019). Amid the current pandemic, because of the high necessity of financial engagement in the countries health care sector, a possibility has emerged to cut the defense budget after raising questions about the necessity of using a high amount of budget in defense sector without giving proper importance to the internal sector (Kheel, 2020).

In the post-WWII era, the Americans had the tacit support of Europe in all its policies, including the war. But Trump's 'America First' policy has suddenly isolated Europe in international politics, particularly during the COVID-19 crisis. The announcement of a halt to air traffic with Europe (Alderman, 2020) has angered Europeans. Those who have been caring for the United States for so long as a superpower also realise the weakness of the United States. However, this overall downturn of the US policies and positions shows that it may no longer be called a superpower.

\section{China}

The rise of China in the early twenty-first century, especially its growing economy, has made it one of the leading contenders for global leadership. This seems more acceptable given the level of China's increasing cooperation in tackling the coronavirus. While all the countries in the world are struggling to cope with the internal shocks during the COVID-19 pandemic, China is moving forward to prevent pandemics in its own country as well as in other countries. Such efforts of China to fight against the COVID-19 have become a crucial factor to the world leaders as it increases China's international reputation and its geopolitical power (Stockwin, 2020). 
China is cooperating with all coronavirus-affected countries to prevent further spread of the pandemic. China had sent medical equipment along with medical teams to several European countries including Italy, Spain, France, Germany, and also to Serbia. Particularly, Italy - the first G7 country that signed a MoU with China to participate in the BRI (Okano-Heijmans \& Kamo, 2019), had seen China extend a helping hand, when other EU countries had not responded to their requests. Such diplomatic endorsement of China helps to strengthen Sino-Italian bilateral relations, which is seen as a great success in implementing (Campbell \& Doshi, 2020) China's OBOR diplomacy in Europe. Again, in Eastern Europe, particularly in Serbia, China had sent immense medical equipment while Serbia declared European solidarity as a 'fairy tale' (Campbell \& Doshi, 2020). At the same time, to prevent the outbreak of the pandemic, China suggested the promotion of public health cooperation with 17 Central and Eastern European countries (CEECs) -a framework of China-CEEC, '17+1' (Kawashima, 2020).

Besides Europe, China also extends its helping hand to other continents as well. In Africa, in becoming a partner of the African Centres for Disease Control and Prevention (Africa CDC) (Brinza, 2020), China, along with some of their companies such as Huawei and ZTE - are taking necessary measures and sending medical assistances and investing in e-health technologies. On the other hand, in Asia, China showed its solidarity to all coronavirus-affected countries and provided medical equipment including facemasks, testing kits and personal protective equipment. Even during this pandemic, China has granted duty-free access to 97 percent of Bangladeshi products to its market ("97\% Bangladeshi Products to Get Duty-Free Access to China," 2020). While China's growing ties with Bangladesh and Nepal are seen as a consequence of the recent border conflict with India, China's cooperation in times of crisis will certainly serve as a softening of these small states towards China.

Beyond this cooperation with different states, with the help of WHO, China is trying to implement its global Health and Silk Road (HSR) strategy - offering infrastructure development, capacity building, and identification, prevention, and control of diseases (Pal, Bhatia, \& Singh, 2020) - while focusing on a 'hub-and-spoke' model where China would be the centre. Through HSR, China is trying to find out several new markets for its products, particularly with OBOR partner countries, where these partners would be new incubators for China's technologies.

Today, everyone is trying to control the coronavirus by following the Chinese model, no matter how much the West blames China for taking missteps and hiding information in the beginning. Everyone is following the same formula that China used to take - lockdown, test, isolation, and treatment. Although China is now to be emulated by announcing control of the coronavirus within two and a half months and returning to normal life, the battle is not over yet. Moreover, China has maintained its superiority by helping others despite criticism from the West. At the same time, China is sending a message to the world that while the United States is scrambling to tackle their problems, China has emerged as an ambassador who has shouldered a huge responsibility, especially to save the world from the COVID-19 pandemic. 


\section{US-China tensions leading up to COVID-19}

In the event of a global pandemic, it is the responsibility of the world's leading countries to lead the way in eradicating it. At the same time, this emerging situation is a challenge for them as their negligence or wrong decisions may lead the world to a difficult situation. Again, in this pandemic situation, the world is at greater risk when the world leaders are engaged in various conflicts, particularly to lead the post-pandemic global order. The COVID-19 pandemic is a testament to such a situation, where the two most influential powers of the world -the United States and China - are embroiled in growing political tensions and disputes over the coronavirus, among other matters.

The feud between the two countries escalated during the coronavirus period, though it began earlier with Donald Trump's 'America First' policy. Initially, this policy triggered a trade war between the two giants (Schlesinger, 2019) and has had an impact on the current COVID-19 pandemic situation. The ongoing culture of 'blame game' (Rae, 2020) and 'conspiracy theory' (Chunshan, 2020) between the two countries over the pandemic are exacerbating their conflicts which contains negative consequences and hampers the prevention activities. In particular, US President Trump's actions against the WHO for working in favor of China, and the announcement of a cut-off of financial aid to the organisation have completely weakened the WHO's political base in the current crisis environment. At the same time, the forthcoming US national election is a major issue behind the blame given to China by the United States, where Trump seeks to use China as a shield to cover up his failure to deal with the coronavirus pandemic within his country.

On the other hand, while the United States has been forced to adopt an inward policy, China is rushing across the world with its medical assistance to fight against the pandemic, which has largely countered the actions against her. Besides, in terms of the blame game, China is not far behind the United States. While the United States is calling the coronavirus as the 'Wuhan Virus', China is blaming the United States military over the spreading of the deadly virus (Chunshan, 2020). However, in this pandemic situation, this irrational relationship between the two world powers and their craziness to lead the world are ultimately leaving the people in a state of despair, which consequences are going to be dreadful.

\section{CHINA'S DESIRE TO CHANGE GLOBAL ORDER AND THE IMPLICATION OF OBOR}

Since the change in leadership in China, Xi Jinping's extraordinary governance has led to China becoming one of the leading powers in the world, especially in the global economy. Before $\mathrm{Xi}$, over the past few decades, China's role in the international arena was largely determined by Deng Xiaoping's '24 Character' strategy - observe calmly; secure our position; cope with affairs calmly; hide our capacities and bide our time; be good at maintaining a low profile; and never claim leadership (Benjamin \& Davies, 2020). Relying on this strategy, China largely implemented its 'slow-moving' policy and 
ascertained its foreign policy very carefully so that its silent development would not pose a threat to anyone, particularly to the United States.

But after Xi Jinping came to power in China in 2012, the dynamics of global leadership began to change, with China establishing itself as one of the world's leading contenders. In that case, Xi's 'One Belt, One Road (OBOR)' initiative is considered as the biggest factor behind this emerging China, which is largely influencing the international economic order (Nie, 2016). OBOR is the flagship development strategy of China under Xi's administration with the main goal of reviving the historic 'Silk Road' with the land-based 'Economic Belt' and the sea-bound 'Maritime Silk Road' (Ferdinand, 2016), and to expand inter-continent communication, cooperation and trade between China, Asia, Africa, and Europe through land and sea connectivity. According to the Chinese dream, the success of the OBOR policy would be a great resurgence of the Chinese nation and could maximise its dreamt place in the global order.

As part of the OBOR project, China attaches the same importance to South and Southeast Asia as it does to the Middle East, Africa, and Europe. Particularly, to implement OBOR in South Asia, the BCIM Economic Corridor (Sajjanhar, 2016) has been developed based on regional cooperation between Bangladesh, China, India, and Myanmar. Similarly, the China-Pakistan Economic Corridor (CPEC) has been established as a basis for cooperation between China and Pakistan where China's main focus is to make maximum use of its production and export capacity.

On the other hand, in the wake of the current COVID-19 pandemic, this 'OBOR' policy has further eased China's desire to change the global order and has played a leading role in establishing China as a truly global leader. As the traditional security concept is not working well to ensure human safety, therefore, in the post-COVID-19 era, the issue of health security will be more important in the national policy of each country than before. In this context, the idea of China's 'Health Silk Road (HSR)' (Hu et al., 2017) - a little component of OBOR, is quite strong.

Since 2015, China has desired to form public health governance (Pal et al., 2020) and the recent outbreak of coronavirus has provided an opportunity to launch the initiative of HSR under the OBOR policy. By implementing the HSR, China is executing its OBOR policy and establishing itself as a global health leader by providing necessary medical assistance to the coronavirus-affected countries, especially giving importance to the countries connected to the OBOR project. Thus, the HSR is giving China the prospect to lead the global health sector to ensure the safety of humans in the post-COVID-19 era, which is China's cherished dream.

\section{CHALLENGES OF CHINA TO LEAD THE POST COVID-19 GLOBAL ORDER}

China's rise in the twenty-first century, especially its pioneering role during the COVID19 pandemic, makes it reasonable to consider China as one of the major actors in the post-COVID-19 world order. Various global debatable measures by the United States and its inward policy during the COVID-19 crisis are increasing China's chances. In addition, 
the quick response of China to fight against the current pandemic has successfully conquered the mind of most of the countries. But, fighting against the pandemic or responding quickly to the coronavirus-affected countries is not enough to make China a world leader. The following are some major challenges that China would face to become a world leader in the post-COVID-19 era.

\section{Geographical Constraints and antagonist neighbors}

Geographically, China is at a disadvantage compared to the United States, especially as the position of its rival neighbors puts China in even greater danger. Where the United States has friendly neighbours like Canada, China has conflicts with its neighbours, particularly with India, Japan, Vietnam, and the Philippines (Fravel, 2020), which poses a big threat to fulfill their dreams. China's industry is largely dependent on Middle Eastern raw materials, and the Indian Ocean is the main sea route for transporting these raw materials. The growing presence of the United States and the Indian Navy in the Indian Ocean has always put China in an awkward position (Brewster, 2019). As well as the ongoing border crisis with India, the ongoing conflict with Japan, and some other Southeast Asian countries over the South China and the East China Seas, tensions with Taiwan and Hong Kong have put China under constant global pressure.

On the other hand, China is the major destination of Japanese investments since the 1970s. Although Japan was forced to adopt a 'China plus One' policy in the wake of growing anti-Japanese movement in China in 2005 (Brooke, 2005), and moved a significant number of Japanese industries to Southeast Asia, China remains a major destination in Japanese foreign direct investment (FDI). But again, due to the difficulties faced by Japanese companies based in China in the wake of the newly emerging COVID19 pandemic, the Japanese government has decided to relocate their industries from China (Kuo, 2020). In this case, besides Southeast Asia, some South Asian countries, especially India and Bangladesh are going to benefit. This growing tendency of Japan towards India will further strengthen the very concept of 'Enemy of my enemy is my friend' in international politics, and will hinder China's global leadership.

\section{Challenges to implementing OBOR policy}

Although China has long dreamed of 'OBOR' policy and worked on various plans, its proper implementation is still in doubt. Here, India is the biggest hurdle to China while the border crisis between these two countries is ongoing. Though according to China, its main purpose is to connect Mainland China with a good number of countries and to expand international trade and connectivity, India is concerned about the hidden objective of these Chinese flagship projects. India's major concern is about China's increasing economic and geopolitical influence in the region and its presence in the strategically important Indian Ocean will increase. More importantly, India feels that the presence of Pakistan-occupied Kashmir in the China-Pakistan Economic Corridor (CPEC) (Pandit, 2018), which is part of the OBOR, poses a threat to India's sovereignty. 
Even, India is repeatedly pressuring its allies not to allow China to set up seaports in the region. As a result, India and its allies -United States and Japan - have ruled out the possibility of building a deep seaport by China on Sonadia Island of Bangladesh (Shepard, 2016). As Sonadia could be the most desired pearl by China, its establishment would be the supreme threat to India. Besides, relations with China in some small countries in South Asia and Africa are not positive, especially the unfortunate incident with the seaport of Hambantota with Sri Lanka (Abi-Habib, 2018) has caught the attention of the whole world. As a result, it will be a bit of a challenge for China to reestablish bilateral and trade relations with different countries - this could hamper the implementation of its 'OBOR' policy.

On the other hand, coronavirus has hit abruptly and has also delayed the implementation of the OBOR. A report released by Refinitiv showed that compared to a certain period in 2019, the number of new projects has dropped by 15.6 percent - whose value fell 64.4 percent (Loh, 2020). However, the effects of the coronavirus and the reluctance and hostility of China's neighboring states appear to be largely tied to China's 'OBOR' implementation.

\section{State system and Conspiracy Theories amid COVID-19}

China's state system, and other areas such as economic, political, social, and cultural, appear to be very different from others. Even, China does not uphold the values that are emerging in the new world order. It might be difficult to make the model of an authoritarian government globally acceptable with only a strong economy where a large number of countries follow different state systems. Besides, democracies have unique economic, diplomatic, and military advantages in long-run geopolitical competitions. So, it would be difficult for China to be able to replace the United States in global leadership in post-COVID-19 global politics.

In addition, a good number of conspiracy theories have spread simultaneously from both parties. A good number of countries still believe that this coronavirus is made in Chinese laboratories and its Belt and Road Initiative (BRI) is the main way of this contagion (Brinza, 2020). When China sells medical equipment amid the pandemic, the critics termed it as China's 'mask diplomacy'. To some extent, this pandemic has dented the position of China internationally, particularly after China's sluggish response to inform both the domestic and global community about the true image of coronavirus despite the experience of SARS in 2002 (Pulipaka \& Ratna, 2020). Rather, some Chinese high officials have spread conspiracy theories that it was spread by the US military - this firmly raised questions about the professionalism of the Chinese officials.

\section{Challenges to regain China's competencies}

For the sake of publicity by the United States, it is widely believed that the coronavirus has become a pandemic due to China's negligence and concealment of information (“China Didn't Warn Public of Likely Pandemic for 6 Key Days," 2020). For that reason, 
in the post-COVID-19 period, firstly, the main task for China will be to restore its reputation. This would be very difficult as it is a well-known fact in the world community that the virus originated from China. Secondly, China needs to recover its economy in the post-COVID-19 era. Since China is the best destination for investment, and many industries located in China have closed down during the coronavirus outbreak in China, and are looking for alternative locations, it will be quite challenging for China to hold on to these companies. Facing the challenges to continue the production in China, Japan among the first countries to encourage its companies to leave China - has offered US\$2.3 billion to leave China and (move) back to Japan (Reynolds \& Urabe, 2020).

Following the government's decision, companies like Toyota, Honda, Nissan had to suspend their production (Horiuchi, 2020), and some other Japanese companies have begun to think to shift their industries to other Southeast Asian countries (Wallace, 2018). On the other hand, some European countries like France and Germany, thinking to decrease their dependency on China for certain products (Cerulus, 2020), rather give importance to strengthening European solidarity and produce cars, aerospace (products), and medicines (Cerulus, 2020).

Again, since the United States is the biggest market for Chinese products, China needs to put a lot of emphasis on developing relations with the US. But Trump and his advisers' hostility to China will require China to gain considerable momentum in developing these relationships. Although US National Security Strategy of 2015 during the Obama administration has commented the US-China relations as 'unprecedented' ("National Security Strategy", 2015), the Trump administration has accused it as a security threat for the United States ("National Security Strategy", 2017), pointing out the huge trade deficit between these two countries.

Besides, China needs to pay equal attention to its exports as it has been severely disrupted during the pandemic, for example, Chinese exports of food and clothing to Japan (Kawamoto, 2020). At the same time, due to the loss of purchasing power of people in developing countries due to the impact of the coronavirus, China will also have to face many challenges in exporting goods. However, it would be difficult for China to take the lead if it fails to restore its reputation as well as accelerate its economy to lead the post-COVID-19 world order.

\section{THEORETICAL ANALYSIS}

After WWII, the United States and the Soviet Union controlled international politics for almost half a century under the bipolar world system. The end of the Cold War through the collapsing of the Soviet Union in the 1990s saw the United States establishing its sole dominance in the 'unipolar' world system. In the twenty-first century, China has been at the forefront of the race to become a superpower with a large economy. This rise of China has become a matter of concern to many countries, especially the United States, which has taken several steps to counter China. The trade war was the first incidence of the fight for global leadership. 
During this trade war, the new virus COVID-19 has given the whole world a push, and has reached all corners of the globe in the last several months. The United States, which has led the world for the past few decades, has been hit the hardest by the coronavirus. This new virus has further eased tensions between these two countries, which can be explained by Graham Allison's 'Thucydides Trap' (Allison, 2015) theory. According to this theory, a growing power will come to shocks with an established one (Brown, 2020). The conflicting nature of bilateral relations, rising tensions and the 'blame game' before and during COVID-19 between these two great powers seem to prove the theory sound.

The main contemplation of the theory lies over the powerful insight of the great historian Thucydides where he observed the rise of Athens, which aroused fear for Sparta, which in turn was inspired to participate in the war. This rivalry situation, according to Thucydides, mainly depends on two key issues: the growing development of the rising power and its desire to become stronger, on the one hand, and the fear and the effort to retain the status quo by the established power, on the other (Allison, 2015). History has shown that even the rivalry race between Germany and Great Britain during the Second World War also suggests the precision of the theory. Including these two incidents, according to Allison, over the past 500 years, there were 12 cases out of 16 which resulted in wars (Allison, 2015).

In the case of US-China dichotomy, since the end of the Cold War, the world system has been largely US-centred, where no other power has been able to resist the United States. But, from the beginning of the twenty-first century, China began to shake up the US-centred world order, which inaugurated with a trade war. Through the strong leadership of Xi Jinping, China has moved beyond the Den Xiaoping's '24 Character' strategy (Benjamin \& Davies, 2020) and the 'hide and bide' era to search for its strong position in the international arena following Xi's 'China Dream' (Mohanty, 2013) under the OBOR initiative. Moreover, Xi Jinping has been advancing China's global interests through pursuing an active foreign policy, and in terms of purchasing power parity, China has snatched the top place from the US.

According to the 'Thucydides Trap', the tension created by the trade can also lead to a major conflict. A kind of trade war between the United States and China has been going on since the beginning of the twenty-first century and has intensified in the current COVID-19 period. This situation is putting the United States under a kind of stress, especially in maintaining the balance of power. The rise of China in international politics has emerged as a major threat to the United States (Yongding \& Gallagher, 2020) and is pushing the two rival countries towards a cold war.

On the other hand, the current COVID-19 has led to the reminder of the changing global power from the United Kingdom to the United States in 1956 following the 'Suez moment' whereby the crisis had established the United Kingdom's increasing dependency over the United States (Peden, 2012). The current Sino-US relations, especially during the COVID-19 period, are in many ways comparable to the 1956 Suez crisis. The United States' declining global hegemony; increasing trade deficit with China; 
growing dependency over China in various sectors including technology, medicine, mobile accessories, garments; and its inward policy during the COVID-19 pandemic is making this comparison more credible.

In 1956, with the intervention of the United Nations, the United States, and the Soviet Union, the United Kingdom was forced to leave Kamal Abdul Nasser's Egypt (Brown Derek, 2001) and from the global order as well. It brought the United States and the then Soviet Union as new global powers. For several decades, the United States, after the collapse of the Soviet Union, has become a world leader - having power, economy, and the tendency to stand by the people of the world in any crisis. This mentality of dealing with the crisis with other countries has put the United States in the seat of leadership. However, the Trump administration, having the 'America First' motto, has caused the United States the loss of leadership, and presented itself as a failure.

While Washington is doomed to failure, Beijing has stepped forward to take the global responsibility. China has established trade relations with various countries in the world, especially with South Asia, Southeast Asia, and African countries. Currently, China is speaking and working beyond its boundaries to prevent a global pandemic. To fight the current COVID-19 pandemic, China is providing medical assistance and sending medical teams across the globe and being praised globally. However, this tendency to share global responsibility is making China a big competitor to the United States and giving China an enormous opportunity to lead the post-COVID-19 global order. If China can finally lead the world in tackling this disaster, it can overturn the global structure. This global rise of China could lead to another Suez Crisis-like event of 1956, but perhaps without a bloody war, or another cold war.

\section{CONCLUSION}

The world order that relied heavily on the United States after the collapse of the Soviet Union, has been witnessing a new global upheaval - China, since the beginning of the twenty-first century. Earlier, particularly in the post 9/11-world system, the main objective of the US's foreign policy was to attack any country under the suspicion of 'terrorism' following its 'war on terror' strategy. This right was not given by anyone, but they have become entitled to this right by force of arms. They have destroyed so many cities and towns, killed, crippled, and orphaned so many people, interfered with the freedom and sovereignty of the countries and did enormous damage to human civilisation and values in the process. Afghanistan, Iraq, Syria, and Libya are the real evidence of the devastation.

This anarchy of the United States and its disregard for international law are creating a kind of anti-United States sentiment globally. In this case, the emergence of an alternative leader, like China, could be welcomed worldwide. In particular, China's growing economy, its strong position in international politics, and its increasing trade relations with other countries are putting China ahead in providing global leadership. Moreover, the desire of China to lead the global order is now seeing the light of hope due to the spread of the current COVID-19 pandemic. 
Amid the outbreak of COVID-19 pandemic, states' dependency over China has increased, although it was thought that COVID-19 would change the culture of global dependency and eliminate globalisation. However, according to Kishore Mahbubani ( 2020) from the National University of Singapore, globalisation will not stop, just that its focus will change. He pointed out that, 'The COVID-19 pandemic will not fundamentally change the nature of the world's economy. Rather, it will accelerate the change that has already begun. Instead of US-centric globalisation, the economy will lean towards Chinacentric globalisation."

On the other hand, the failure to ensure health care, the rising unemployment rate, and the collapse of the export sector will plunge developing countries into a major crisis. By properly cooperating with these developing countries in tackling the crisis, China will be able to strengthen its global leadership. At the same time, the haphazard policy of China, its uncomfortable relations with the United States and its neighboring countries, i.e. India, and its communist government system could bring some challenges to fulfill its dream to lead the post-COVID-19 global order.

However, though it is difficult to predict very early what kind of changes will be held in the post-COVID-19 world order, it can be assumed that the post-COVID-19 world system is undergoing major changes in politics, economy, and society. At the same time, considering the paradoxical relations between the United States and China, it would be difficult for any single country to lead the post-COVID-19 global order. Rather, it can be said that the post-COVID-19 world structure will be built through engaging in cooperation with China.

\section{REFERENCES}

97\% Bangladeshi products to get duty-free access to China. (2020, June 19). Dhaka Tribune. Retrieved from https://www.dhakatribune.com/business/2020/06/19/5-161more-bangladeshi-products-to-enjoy-zero-tariff-to-chinese-markets-from-july1 ?fbclid=IwAR1tuG-

Abi-Habib, M. (2018, June 25), How China Got Sri Lanka to Cough Up a Port . The New York Times. Retrieved from https://www.nytimes.com/2018/06/25/world/asia/chinasri-lanka-port.html

Al-Sayyid, M. K., Baktiari, B., Barnett, M., Hegasy, S., Hurd, E. S., Lust-Okar, E., Lang, Jr., A. F. (2002), The Impact of 9/11 on the Middle East. Middle East Policy, 9(4), 75-101. Retrieved from https://doi.org/10.1111/1475-4967.00084

Alderman, L. (2020, March 12), 'Massive Shock' and Battered Airline Stocks in Europe With Trump's Travel Ban. The New York Times. Retrieved from Retrieved from https://www.nytimes.com/2020/03/12/business/trump-europe-travel.html

Allison, G. (2015, September 24), The Thucydides Trap: Are the U.S. and China Headed for War? The Atlantic. Retrieved from https://www.theatlantic.com/international/archive/2015/09/united-states-china-warthucydides-trap/406756/

Benjamin, M., \& Davies, N. J. S. (2020, April 1), Could COVID-19 Reshape Global 
Leadership?. Retrieved May 8, 2020, from Common Dreams website:

https://www.commondreams.org/views/2020/04/01/could-covid-19-reshape-globalleadership

Brewster, D. (2019, February 12), China's Limited Role in the Indian Ocean . Real Clear Defense. Retrieved from

https://www.realcleardefense.com/articles/2019/02/12/chinas_limited_role_in_the_i ndian_ocean_114179.html

Brinza, A. (2020, April 2), Some Say China's Belt and Road Helped Create This Pandemic. Can It Prevent the Next One?. The Diplomat. Retrieved from https://thediplomat.com/2020/04/some-say-chinas-belt-and-road-helped-create-thispandemic-can-it-prevent-the-next-one/?fbclid=IwAR3P5nCFkKmpfSZ8gHoEcezccGBRzX8oXARFgCDTzXu0DzOBzHlnGFFda0

Brooke, J. (2005, June 29), Japanese running scared. Financial Review . Retrieved from https://www.afr.com/politics/japanese-running-scared-20050629-jv7bn

Brown Derek. (2001, March 14), 1956: Suez and the end of empire. The Guardian. Retrieved from https://www.theguardian.com/politics/2001/mar/14/past.education1

Brown, K. (2020, June 11), For the US and China, Thucydides' Trap Is Closing. The Diplomat. Retrieved from https://thediplomat.com/2020/06/for-the-us-and-chinathucydides-trap-is-closing/?fbclid=IwAR3aJEDwsWU-XJRO60Qan-R832Vf3ociRW8E76Vxn2rMpAalkJc8XrCCEg

Campbell, K. M., \& Doshi, R. (2020, March 18), The Coronavirus Could Reshape Global Order. Foreign Affairs. Retrieved from https://www.foreignaffairs.com/articles/china/2020-03-18/coronavirus-couldreshape-global-order

Cerulus, L. (2020), Coronavirus forces Europe to confront China dependency. Politico. Retrived from https://www.politico.eu/article/coronavirus-emboldens-europessupply-chain-security-hawks/

Chandy, L., \& Seidel, B. (2016, November 18), Donald Trump and the future of globalization. Retrieved June 23, 2020, from Brookings website:

https://www.brookings.edu/blog/up-front/2016/11/18/donald-trump-and-the-futureof-globalization/

Chatterjee, P., Nagi, N., Agarwal, A., Das, B., Banerjee, S., Sarkar, S., Gangakhedkar, R. (2020), The 2019 novel coronavirus disease (COVID-19) pandemic: A review of the current evidence. Indian Journal of Medical Research, $0(0), 0$. Retrieved from https://doi.org/10.4103/ijmr.IJMR_519_20

"China didn't warn public of likely pandemic for 6 key days" (2020, April 15), The Associated Press. Retrieved from https://apnews.com/68a9e1b91de4ffc166acd6012d82c2f9

Chunshan, M. (2020, March 17), On China, COVID-19, and Conspiracy Theories . The Diplomat. Retrieved from https://thediplomat.com/2020/03/on-china-covid-19-andconspiracy-theories/

"Coronavirus declared global health emergency by WHO" (2020, January 31), BBC News. Retrieved from https://www.bbc.com/news/world-51318246

"Covid - 19 and the Inevitable Economic Catastrophe" (2020, April 10), The Policy Times. Retrieved from https://thepolicytimes.com/covid-19-and-the-inevitableeconomic-catastrophe-or-corona-and-its-after-wrath-on-economy/ 
Ferdinand, P. (2016), Westward ho-the China dream and 'One belt, One road': Chinese foreign policy under Xi Jinping. International Affairs, 92(4), 941-957. Retrieved from https://doi.org/10.1111/1468-2346.12660

Fertl, D. (2020, May 16), COVID-19: The EU has failed a test of solidarity. The Left Berlin. Retrieved on June 23, 2020, from The Left Berlin website: https://www.theleftberlin.com/post/covid-19-the-eu-has-failed-a-test-of-solidarity

Fravel, M. T. (2010), International Relations Theory and China's Rise: Assessing China's Potential for Territorial Expansion. International Studies Review, 12, 505-532. Retrieved from https://doi.org/10.1111/j.1468-2486.2010.00958.x

Fravel, M. T. (2020, February 21), Is China a good neighbor?. The Washington Post. Retrieved from https://www.washingtonpost.com/politics/2020/02/21/mike-pompeocriticized-china-not-respecting-its-neighbors-territorial-integrity-whats-story/

Fuchs, M. H. (2020, May 12), Trump is making America an obstacle in the global fight against Covid-19. The Guardian. Retrieved from https://www.theguardian.com/commentisfree/2020/may/12/trump-is-makingamerica-an-obstacle-in-the-global-fight-against-covid-19

Horiuchi, J. (2020, March 6). Coronavirus uncertainties deal heavy blow to Japan auto industry. Kyodo News. Retrieved from https://english.kyodonews.net/news/2020/03/d0c9dbf983ca-focus-coronavirusuncertainties-deal-heavy-blow-to-japan-auto-industry.html

Hu, R., Liu, R., \& Hu, N. (2017), China's Belt and Road Initiatve from a global health perspective. The Lancet Global Health, 5(8). Retrieved from Doi: https://doi.org/10.1016/S2214-109X(17)30250-4.

Jinchen, T. (2016, June), 'One Belt and One Road': Connecting China and the world. Retrieved on June 23, 2020, from https://www.globalinfrastructureinitiative.com/article/one-belt-and-one-roadconnecting-china-and-world

Kawamoto, A. (2020, February 24), Commentary: The great COVID-19 disruption to Asian economies has begun. Channel News Asia. Retrieved from https://www.channelnewsasia.com/news/commentary/covid-19-wuhan-coronaviruseconomy-impact-trade-supply-chain-12435728

Kawashima, S. (2020, April 2), China and Eastern Europe in the COVID-19 Era. The Diplomat. Retrieved from https://thediplomat.com/2020/04/china-and-easterneurope-in-the-covid-19era/?fbclid=IwAR3ZBPeTFKoemvjdNEHRMMJWPVGyHN2TVVgF_7U39nt0jaV -BWwi8PVcUZ4

Khanna, P. (2016), Connectography: Mapping the Future of Global Civilization. Random Houses Publisher.

Kheel, R. (2020, May 19), Progressives demand defense budget cuts amid coronavirus pandemic. The Hill. Retrieved from https://thehill.com/policy/defense/498509progressives-demand-defense-budget-cuts-amid-coronavirus-pandemic

Kroenig, M. (2020), The Return of Great PowerRivalry: Democracy versus Autocracy from the Ancient World to the U.S. and China. Oxford: Oxford University Press.

Kuo, M. (2020, May 8), Japan prods firms to leave China, affecting ties with Beijing and Washington. The Japan Times. Retrieved from https://www.japantimes.co.jp/news/2020/05/08/national/politics-diplomacy/tokyo- 
china-us-relations-business/\#.XvIDuWgzbIU

Letzing, J. (2020, March 24), How China's COVID-19 recovery could bolster its global influence. Retrieved June 23, 2020, from World Economic Forum website: https://www.weforum.org/agenda/2020/03/how-china-s-covid-19-recovery-couldbolster-its-global-influence/

Loh, D. (2020, July 17), Coronavirus blocks Belt and Road, cutting Q1 project value by 64\%. Nikkei Asian Review. Retrieved from https://asia.nikkei.com/Spotlight/Beltand-Road/Coronavirus-blocks-Belt-and-Road-cutting-Q1-project-value-by64?fbclid=IwAR17sFDkGxHye6NHSdd2MQLV0TP6iCH15R15NOCphekX_1ef4uh jsGEOzSk

Lons, C., Fulton, J., Sun, D., \& Tamimi, N. Al. (2019, October 21), China's great game in the Middle East. Retrieved on June 23, 2020, from European Council on Foreign Relations website: https://www.ecfr.eu/publications/summary/china_great_game_middle_east

Layne, C. (1993), The Unipolar Illusion: Why New Great Powers Will Rise. International Security, 17(4), 5-51. Retrieved from doi:10.2307/2539020

Macias, A. (2019, November 20), US has spent \$6.4 trillion on wars in Middle East, Asia since 2001. CNBC. Retrieved from https://www.cnbc.com/2019/11/20/us-spent6point4-trillion-on-middle-east-wars-since-2001-study.html

Mahbubani, K. (2020, March 20), A More China-Centric Globalization. Foreign Policy. Retrieved from https://foreignpolicy.com/2020/03/20/world-order-after-coroanviruspandemic/

Mcgregor, G. (2020, January 10), As US Iran Conflict Flares, China Becomes Tehran's Last-Ditch Lifeline. Fortune. Retrieved from https://fortune.com/2020/01/10/usiran-sanctions-china/

Mohanty, M. (2013), Xi Jinping and the 'Chinese Dream'. Economic and Political Weekly, 48(38), 34-40. Retrieved from www.jstor.org/stable/23528539.

Murtezaj, V. Z. (2010), How Has Globalization Shaped the Course of International Relations: Are We Moving Closer Or Further Apart? IFAC Proceedings Volumes, 43(25), 145-148. Retrieved from https://doi.org/10.3182/20101027-3-XK4018.00029

National Security Strategy (2015). The White House. Retrieved from https://obamawhitehouse.archives.gov/sites/default/files/docs/2015_national_securit y_strategy_2.pdf.

National Security Strategy (2017). The White House. Retrieved from https://www.whitehouse.gov/wp-content/uploads/2017/12/NSS-Final-12-18-20170905.pdf

Nie, W. (2016), Xi Jinping's Foreign Policy Dilemma: One Belt, One Road or the South China Sea? Contemporary Southeast Asia, 38(3), 422-444. Retrieved from www.jstor.org/stable/24916765.

Okano-Heijmans, M., \& Kamo, T. (2019), Engaging but Not Endorsing China's Belt and Road Intitiative. Clingendael Institute. doi: 10.2307/resrep21306.

Pal, D., Bhatia, R., \& Singh, S. V. (2020, June 11), Health Silk Road - How China plans to make BRI essential in Covid-hit South Asia. The Print. Retrieved from https://theprint.in/opinion/health-silk-road-how-china-plans-to-make-bri-essentialin-covid-hit-south- 
asia/439603/?fbclid=IwAR2de6jpE5MUhirT4JoWgUGNfDLMaMnWauRHHr3a1L FXu2Bi2y3wNSmM21U

Pandit, R. (2018, July 12), China Pakistan Economic Corridor: India expresses strong opposition to China Pakistan Economic Corridor, says challenges Indian sovereignty . The Economic Times. Retrieved from https://economictimes.indiatimes.com/news/defence/india-expresses-strongopposition-to-china-pakistan-economic-corridor-says-challenges-indiansovereignty/articleshow/57664537.cms?from=mdr

Peden, G. (2012), Suez and Britain's Decline as a World Power. The Historical Journal, 55(4), 1073-1096. doi: 10.1017/S0018246X12000246.

Pinos, J. C., \& Radil, S. M. (2020, June 12), The Covid-19 pandemic has shattered the myth of a borderless Europe. Retrieved on June 23, 2020, from https://blogs.lse.ac.uk/europpblog/2020/06/12/the-covid-19-pandemic-has-shatteredthe-myth-of-a-borderless-europe/

Pulipaka, S., \& Ratna, P. (2020, March 28), COVID-19 and the mirage of a China-led international order. The Economic Times. Retrieved on May 8, 2020, from The Economic Times website: https://economictimes.indiatimes.com/blogs/etcommentary/covid-19-and-the-mirage-of-a-china-led-international-order/

Rae, J. (2020, March 7), The COVID-19 blame game . CGTN. Retrieved from https://news.cgtn.com/news/2020-03-07/The-COVID-19-blame-gameOELSBouiZ2/index.html

Reynolds, I., \& Urabe, E. (2020, April 8), Japan to Fund Firms to Shift Production Out of China. Bloomberg. Retrieved from https://www.bloomberg.com/news/articles/202004-08/japan-to-fund-firms-to-shift-production-out-of-china

Sajjanhar, A. (2016), Understanding the BCIM Economic Corridor and India's Response. ORF Issue Brief, 147. Retrieved from https://www.orfonline.org/wpcontent/uploads/2016/06/ORF_IssueBrief_147.pdf

Schlesinger, J. M. (2019, December 15), Trump's 'America First' Trade Vision Comes Into Focus on Three Fronts. The Wall Street Journal. Retrieved from https://www.wsj.com/articles/trumps-america-first-trade-vision-comes-into-focuson-three-fronts-11576436055

Schweller, R. L., \& Pu, X. (2011), After Unipolarity: China's Vision of International Order in an Era of U.S. Decline. International Security 36(1), 41-72. Doi: 10.1162/ISEC_a_00044.

Shepard, W. (2016, June 7), Bangladesh's Deep Sea Port Problem. The Diplomat. Retrieved from https://thediplomat.com/2016/06/bangladeshs-deep-sea-portproblem/

Stockwin, A. (2020, April 15), How will COVID-19 reshape the world?. East Asia Forum. Retrieved from https://www.eastasiaforum.org/2020/04/15/how-will-covid19-reshape-the-world/

Szuplat, T. (2017, February 3), Why Trump's “America First” Policy Is Doomed to Fail. The New Yorker. Retrieved from https://www.newyorker.com/news/news-desk/whytrumps-america-first-policy-is-doomed-to-fail

Wallace, C. (2018). Leaving (north-east) Asia? Japan's southern strategy. International Affairs, 94(4), 883-904. Retrieved from https://doi.org/10.1093/IA/IIY027

Wikan, V. S. (2015, March 21), What Is 'Neoliberalism', and How Does It Relate to 
Globalization?. Retrieved on June 23, 2020, from E-International Relations website: https://www.e-ir.info/2015/03/21/what-is-neoliberalism-and-how-does-itrelate-to-globalization/

Wintour, P., \& Rankin, J. (2020, March 26), G20 leaders issue pledge to do "whatever it takes" on coronavirus. The Guardian. Retrieved from https://www.theguardian.com/world/2020/mar/26/g20-leaders-issue-pledge-to-dowhatever-it-takes-on-coronavirus

Yongding, Y., \& Gallagher, K. P. (2020, April 24), COVID-19 and the Thucydides Trap. Retrieved on June 23, 2020, from project Syndicate website: https://www.projectsyndicate.org/commentary/covid-thucydides-trap-by-yu-yongding-and-kevin-pgallagher-2020-04?barrier=accesspaylog 